\title{
Airway smooth muscle cells: contributing to and regulating airway mucosal inflammation?
}

\author{
K.F. Chung
}

Airway smooth muscle cells: contributing to and regulating airway mucosal inflammation? K.F. Chung. (C) ERS Journals Ltd 2000.

ABSTRACT: In addition to its contractile properties, airway smooth muscle may contribute to the pathogenesis of asthma by increased proliferation, and by the expression and secretion of pro-inflammatory cytokines and mediators.

Studies of airway smooth muscle cells in culture have shown that many mitogenic mediators can induce proliferation, and that these may therefore, contribute to the increase in airway smooth muscle mass observed in asthma. Other mechanisms for airway smooth muscle proliferation include the interaction with inflammatory cells such as T-cells and eosinophils.

Airway smooth muscle cells may also be a source of inflammatory mediators and cytokines, in particular chemokines, thus implicating airway smooth muscle cells as contributors to the inflammatory mechanisms of asthma. The pro-activating signals for converting airway smooth muscle cells into a proliferative and secretory cell in asthma are unknown, but may include viruses and immunoglobulin E. Airway smooth muscle contractility may also be altered in response to inflammation.

Airway smooth muscle cells may play an important interactive role with inflammatory and other structural cells, contributing to inflammation, injury and repair of the airways. Such a recognition makes it imperative to consider the airway smooth muscle as a target of therapeutic drugs for suppressing not only the contractile but also the proliferative and secretory effects of asthma.

Eur Respir J 2000; 15: 961-968.

In inflammatory diseases of the airways, the airway smooth muscle has long been regarded as mainly passive, responding only to the release of bronchoconstrictor mediators from other neighbouring cells by contraction, leading to narrowing of the airways and airways obstruction. The mechanical, structural and biochemical properties of the contractile proteins of the airway smooth muscle have been relatively well studied [1], and an increase in the contractile properties of the airway smooth muscle in asthma is considered to be a fundamental abnormality of the disease [2]. Contractile mediators such as histamine and leukotrienes are important in inducing airway smooth muscle shortening and contraction [3]. The maximum capacity and velocity of shortening in human bronchial smooth muscle from patients with asthma are greater than those from healthy subjects [1]. An increase in force generation of the airway smooth muscle mass may result from increased proliferation; in addition, other concomitant factors may also result from an increased airway smooth muscle mass such as increased thickening of the airway wall, which may contribute to overall contractile hyperresponsiveness [4-6].

In vitro studies indicate that the airways smooth muscle cell can maintain a proliferative phenotype in response to contractile agents, inflammatory mediators and growth factors [7]. Morphometric studies of airway smooth muscle in asthma have demonstrated that there is an increase in airway smooth muscle mass which is accounted for by hyperplasia and also by hypertrophy $[4,5]$. Such an increase in airway smooth muscle mass could contribute to the exaggerated airway narrowing observed in asthma $[6$, 8 ] and may result from the action of growth factors released during the chronic inflammatory process. It has yet to be demonstrated that airway smooth muscle in asthma has a proliferative phenotype. However, in some animal models, increased proliferation of the airway smooth muscle following repeated allergen exposures after sensitization occurs [9-11]. In addition to the direct interaction of growth factors on the airway smooth muscle, the possibility that inflammatory cells, such as T-cells, could

Previous articles in this series: No. 1: S.J. Gunst, D.D. Tang. The contractile apparatus and mechanical properties of airway smooth muscle. Eur Respir J 2000; 15: 600-616. No. 2: A. James, N. Carroll. Airway smooth muscle in health and disease; methods of measurement and relation to function. Eur Respir $J$ 2000; 15: 782-789. 
interact directly with the airway smooth muscle to induce proliferation has been raised [12]. Removal of serum factors that induce proliferation of airway smooth muscle in vitro following confluence results in a population of elongated cells with an ability to shorten considerably [13], together with an increase in smooth muscle $\alpha$-actin and myosin heavy chain [14]. The question is whether there is such a heterogeneity of airway smooth muscle cells in vivo particularly in thickened airway smooth muscle of patients with asthma, and whether these cells contribute to the increased responsiveness of the airways.

Studies derived mainly from isolated airway smooth muscle cells in culture indicate that the airway smooth muscle can also exhibit a synthetic potential with the elaboration of inflammatory mediators including cytokines, and also importantly, the muscle can respond to its inflammatory milieu by expressing and releasing proteins that render the muscle cell a potentially active participant of the inflammatory response. Therefore, the airway smooth muscle could exhibit various states: a synthetic phase, a proliferative phase as well as a contractile phase (fig. 1). These states may coexist in the same cell and may be examined separately in airway smooth muscle cells in vitro.

\section{Airway smooth muscle cells in culture}

Cultured airway smooth muscle cells $[15,16]$ have provided a convenient model system for studying the regulation of a wide range of airway responses at the cellular level. The most common method used is to dissociate cells from a minced preparation of airway smooth muscle, usually from trachealis or sometimes from the major bronchi, using collagenase and elastase to degrade collagen and elastin from the associated matrix. Other methods include the use of small explants of dissected smooth muscle to generate primary cultures. After growing to confluence usually in the presence of foetal calf serum (FCS), the cells can be removed from their growth support and reseeded at subconfluent cell density and allowed to proliferate again. Airway smooth muscle cells in culture possess specific features recognized to be characteristic of cultured smooth muscle cells in general. Nonmuscle contaminants such as epithelial or connective tissue cells (fibroblasts) can be distinguished from airway smooth muscle cells by immunostaining for smooth

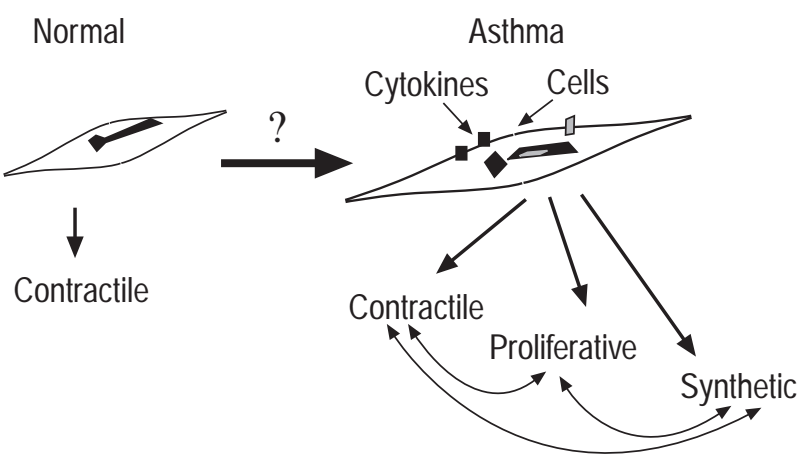

Fig. 1. - Potential changes in airway smooth muscle phenotypes in asthma. Through the action of cytokines and inflammatory cells, airway smooth muscle cells may become hypercontractile, proliferate and synthesize pro-inflammatory cytokines and chemokines. The question is whether the same airway smooth muscle can assume these different phenotypes or whether different airway smooth muscle cell phenotypic subsets are present in asthma. muscle $\alpha$-actin and smooth muscle specific myosin heavy chain. In airway smooth muscle cells, the pattern of staining is that of filamentous contractile proteins arranged in parallel to the long axis of the cells. Usually little change in cell number occurs over the first 3-4 days after plating, with few cell-to-cell contacts existing, with spindle-shaped morphology that is characteristic of cultured vascular smooth muscle cells. Cell numbers begin to increase after 4 days, until confluence is reached by 7-10 days after initial seeding. At confluence, the cells exist in several layers and cultures exhibit a hill and valley pattern typical of airway smooth muscle cells in culture.

The contractile phenotype of airway smooth muscle cells under culture is well recognized in enzyme dissociated cells seeded in primary culture within $24-48 \mathrm{~h}$, with intense immunostaining for muscle specific contractile proteins and with visible contraction to constrictor agonists. Serum deprivation allows the acquisition of a subpopulation of myocytes with a morphological and functional contractile phenotype [14]. In the presence of proliferating stimuli, such as FCS, contractile airway smooth muscle changes into a "synthetic" phenotype, characterized by: increased mitogenic activity; expression of intracellular organelles associated with synthesis; and a decrease in immunostaining for smooth muscle specific contractile proteins. In proliferating tracheal smooth muscle cells, the levels of smooth muscle myosin heavy chain are markedly reduced with a reduction in messenger ribonucleic acid (mRNA) for this protein and $\alpha$-actin, with some reduction in myosin light chains [17]. The synthetic cells produce extracellular matrix components and also autocrine growth-promoting factors, and these could in turn influence the contractile or synthetic phenotype, as described primarily in vascular smooth muscle cells [1820]. In vascular smooth muscle cells, phenotypically distinct cells with enhanced growth potential have been shown to exist within the normal arterial media [21].

\section{Synthesis of pro-inflammatory proteins}

Studies of cultures of airway smooth muscle cells have now demonstrated that these cells can release several inflammatory mediators under various conditions of stimulation. This raises the likelihood that airway smooth muscle cells may contribute to chronic inflammatory processes in the airway. Dissociated airway smooth muscle cells in culture usually grown to a stage of confluence, then serumdeprived, have been studied. A list of these inflammatory mediators is shown in table 1 .

\section{Products of lipid metabolism}

Airway smooth muscle cells are an important source of cyclooxygenase products with predominantly prostaglandin $(\mathrm{PG}) \mathrm{E}_{2}$ and prostacyclin, with relatively little formation of thromboxane following stimulation with a mixture of interleukin (IL)-1 $\beta$, tumour necrosis factor (TNF) $\alpha$ and interferon (IFN) $\gamma$ ("cytomix"), through the induction of the cyclooxygenase enzyme-2 (COX-2) [22]. Bradykinin also causes release of $\mathrm{PGE}_{2}$ from human airway smooth muscle cells, also mediated through the induction of COX-2 [23]. Cytokines also induce the secretory form of phospholipase $\mathrm{A}_{2}$ from airway smooth muscle cells [24]. Cultured human airway smooth muscle cells express mRNA 
Table 1. - Inflammatory cytokines, mediators enzymes and receptors produced by airway smooth muscle cells in culture

\begin{tabular}{lccc}
\hline $\begin{array}{l}\text { Cytokines/ } \\
\text { chemokines }\end{array}$ & $\begin{array}{c}\text { Growth } \\
\text { factors }\end{array}$ & $\begin{array}{c}\text { Receptors/ } \\
\text { surface } \\
\text { molecules }\end{array}$ & $\begin{array}{c}\text { Lipid } \\
\text { mediators/ } \\
\text { enzymes }\end{array}$ \\
\hline $\begin{array}{l}\text { MCP-1, 2 \& } 3 \\
\text { RANTES }\end{array}$ & $\begin{array}{c}\text { PDGF-BB } \\
\text { MMP-1 }\end{array}$ & $\begin{array}{c}\text { IL-2R } \\
\text { IL-12R }\end{array}$ & PGE $_{2}$ \\
Eotaxin & Stem cell factor & IFN $\gamma$ R & NOS \\
IL-8 & & ICAM-1 & \\
GM-CSF & & VCAM-1 & \\
IL-6 & & CD44 & \\
IL-11 & CD40 & \\
IL-5 & & MHC Class 2 & \\
IFN $\gamma$ & & & \\
IL-2 & & & \\
IL-12 & & & \\
LIF & & & \\
\hline
\end{tabular}

MCP: monocyte chemoattractant protein; PDGF: platelet-derived growth factor; IL: interleukin; R: receptor; $\mathrm{PGE}_{2}$ : prostaglandin $\mathrm{E}_{2}$; RANTES: regulated upon activation, normal T-cell expressed and secreted; MMP: matrix metaloproteinase; s-PLA 2 : secretory phospholipase A; IFN $\gamma$ : interferon $\gamma$; NOS: nitric oxide synthase type 1; ICAM: intercellular adhesion molecule; GM-CSF: granulocyte-macrophage colony-stimulating factor; VCAM: vascular cell adhesion molecule; MHC: major histocompatibility complex; LIF: leukaemia inhibitory factor.

for enzymes of the 5-lipoxygenase pathway, including 5lipoxygenase, epoxide hydrolase, leukotriene (LT) $\mathrm{C}_{4}$ synthase and $\gamma$-glutamyl transpeptidase, as well as receptors for $\mathrm{LTB}_{4}$ and Cys-LT 1 receptors [25]. The expression of these enzymes and receptors was increased following exposure to human atopic serum or to IL- $1 \beta$.

\section{Chemokines}

Chemokines such as regulated upon activation, normal T-cell expressed and secreted (RANTES), eotaxin, and monocyte chemoattractant protein (MCP)-3 are chemoattractant cytokines which are expressed in asthmatic airways, and may be important in causing chemotaxis and activation of inflammatory cells such as eosinophils, Tcells and macrophages [26-29]. RANTES is an eosinophil and T-cell chemoattractant. Stimulation of airway smooth muscle cells with TNF $\alpha$ caused expression of RANTES mRNA and protein release, an effect augmented by IFN $\gamma$ [30]. The RANTES fraction from the supernatants caused eosinophil chemotaxis in vitro. The T-helper (Th)-2 T-cell derived cytokines, IL-4, IL-10 and IL-13, as well as dexamethasone inhibited RANTES mRNA and protein expression. The more selective eosinophil chemoattractant, eotaxin, is also expressed in human airway smooth muscle cells stimulated by IL- $1 \beta$ or TNF $\alpha[31,32]$. Both IL-1 $\beta$ and TNF $\alpha$-induced release of eotaxin was not inhibited by corticosteroids, in contrast to the release of RANTES [31]. The eosinophil chemoattractant activity of stimulated airway smooth muscle supernatants appears to be predominantly accounted for by RANTES and eotaxin $[30,32]$. Other $\mathrm{C}-\mathrm{C}$ chemokines that are released include MCP-1, -2 and -3 from airway smooth muscle cells stimulated with a mixture of IL- $1 \beta, \mathrm{TNF} \alpha$ and IFN $\gamma$, effects inhibited by dexamethasone but not by the Th2 cytokines, IL-4, IL-10 and IL-13 [33, 34]. There is no evidence for the release of macrophage inflammatory protein-1 $\alpha[30]$. Following stimulation with IL-1 $\beta$ and bradykinin, airway smooth muscle cells can express and release IL-8, a potent neutrophil chemoattractant $[35,36]$.

\section{Pro-inflammatory cytokines}

Airway smooth muscle cells generate granulocyte-macrophage colony-stimulating factor (GM-CSF) under stimulation with the cytokine mixture of IL-1 $\beta$, TNF $\alpha$ and IFN $\gamma$ [37]. Supernatants of airway smooth muscle cells stimulated by IL- $1 \beta$ caused increased survival of eosinophils [38], an effect blocked by an anti-GM-CSF antibody, thereby implying GM-CSF as the cytokine responsible for eosinophil survival. Human airway smooth muscle cells are also potent producers of IL-11 when stimulated with IL- 1 and transforming growth factor (TGF) $\beta 1$ in combination, and when incubated with respiratory syncytial virus and parainfluenza virus type 3 [39]. Other IL-6-type cytokines such as IL-6 and leukaemia inhibitory factor are also released on stimulation with IL-1 and TGF $\beta 1$ [39]. IL-6 is also produced by cross-linking CD40 [40]. Sensitization of airway smooth muscle cells with asthmatic atopic serum leads to the expression and release of IL-5 and IFN $\gamma$, together with the mRNA expression for their receptors. There was no increase in IL-4 expression [41]. There was also enhanced expression of the Th1 cytokines IL-2, IL-12 and IFN $\gamma$, and of their receptors. These results indicate that both Th1 and Th2 cytokines can be produced by airway smooth muscle cells.

\section{Mediators of airway smooth muscle proliferation}

Many studies have characterized the stimulation of airway smooth muscle growth in vitro in response to mitogenic agents such as polypeptide growth factors (e.g. platelet-derived growth factor (PDGF) [42, 43], epidermal growth factor (EGF) [44], insulin-like growth factor (IGF) [45], inflammatory mediators (e.g. endothelin (ET)-1, histamine) and cytokines (e.g. IL-1 $\beta$, TNF $\alpha$ and IL-6). IL- $1 \beta$, TNF $\alpha$ and IL- 6 induce proliferation of airway smooth muscle, but usually in the presence of a cyclooxygenase inhibitor which prevents the induced secretion of protective $\mathrm{PGE}_{2}[46,47]$, The effect of IL-1 $\beta$ appears to be mediated via PDGF formation [48]. Histamine stimulates proliferation via activation of $c$-fos [49], and ET-1 induced proliferation via the stimulation of extracellularregulated kinase microtubule associated protein kinase pathway [50]. More importantly, ET-1 and LTD $_{4}$ amplify the proliferative effect of growth factors such as EGF [51, 52]. In vivo studies in a Brown-Norway rat model show that sulphidopeptide leukotrienes and ET-1 are both involved in allergen-induced increases in airway smooth muscle proliferation $[9,53,54]$. Finally, activated T-cells can adhere to airway smooth muscle and induce its proliferation [12].

In addition to responding to proliferative factors, airway smooth muscle cells can also produce some of the factors that can modulate its proliferation. Nitric oxide is produced from the airways during inflammation. Type I nitric oxide synthase (NOS) is constitutively expressed by cultured human airway epithelial cells, but not Type II NOS (inducible NOS) even after exposure to IL-1 $\beta$, TNF $\alpha$ and 
IFN $\gamma$ [55]. Nitric oxide can inhibit deoxyribonucleic acid (DNA) synthesis and the proliferation of airway smooth muscle. Reactive oxygen species generated by an oxidoreductase of reduced nicotinamide adenine dinucleotide are required for serum or PDGF-induced growth of airway smooth muscle cells [56]. Furthermore, superoxide dismutase mimetics are capable of inhibiting serum-induced proliferation of airway smooth muscle cells [55]. Insulin-like growth factor (IGF) 2 is produced by cultured rabbit airway smooth muscle cells at concentrations that can stimulate proliferation [45]. IGF binding protein (IGFBP)-2 is also produced. An expression of the BB isoform of PDGF (PDGF-BB) mRNA and protein was observed in guinea-pig airway smooth muscle cells on exposure to IL-1 $\beta$, associated with proliferation, which was ablated by antibodies to PDGF-BB [48]. This study by DE et al. [48] suggests that PDGF-BB may be released from airway smooth muscle cells. Other growth factors such as basic fibroblast growth factor may increase the expression of PDGF $\alpha$-receptor and the binding of PDGF-AA to airway smooth muscle cells. An induction of matrix metalloprotease (MMP)-1 by LTD4 in airway smooth muscle has been reported [57]. Since MMP-1 acts as a protease for IGFBP-2, causing its degradation, the effects of IGF can be enhanced, thus explaining the synergy between $\mathrm{LTD}_{4}$ and IGF on airway smooth muscle proliferation. Elevated levels of MMP-1 have been demonstrated in airway smooth muscle cells in patients with asthma [58]. PGE $_{2}$ produced by airway smooth muscle cells is anti-proliferative [59].

Human bronchial smooth muscle cells are also capable of producing stem cell factor which is a ligand of the $c$-kit proto-oncogene and which is an important growth factor for human mast cells [60]. Both soluble and membranebound stem cell factor mRNA are expressed. This indicates that airway smooth muscle cells could increase human mast cells within their vicinity as has been shown in asthmatic airways [61], and that direct release of mediators from mast cells could primarily affect airway smooth muscle.

\section{Interactions of airway smooth muscle cells with pro-inflammatory and immune cells}

Interaction of airway smooth muscle cells with inflammatory cells may occur following expression of cell adhesion molecules on the surface of airway smooth muscle cells which may lead to direct contact of inflammatory cells on airway smooth muscle. There is increased expression of $\alpha 1$ and $\alpha 2$ integrins, very late activation antigen (VLA)-4 and lymphocyte function associated receptor (LFA)-1, in bronchial biopsies of patients with asthma [6264]. Airway smooth muscle cells express intercellular adhesion molecule (ICAM)-1 and vascular cell adhesion molecule (VCAM)-1 at barely detectable levels, but upregulate these adhesion molecules after treatment with TNF $\alpha$ for $24 \mathrm{~h}$. Lipopolysaccharide, IL-1 and IFN also increased ICAM-1 expression, while VCAM-1 expression was increased by TNF and IL-1 [12]. Activation of T-cells is required for adhesion to airway smooth muscle cells. This binding of T-cells to airway smooth muscle is partially prevented when activated T-cells are pretreated with monoclonal antibodies against LFA-1 or when airway smooth muscle cells were pretreated with antibodies to ICAM-1. A combination of antibodies against LFA-1 and VLA-4, or ICAM-1 and VCAM-1 inhibited binding to a greater extent than anti-LFA-1 or anti-ICAM-1 alone. A combination of LFA-1, VLA-4 and CD44 antibodies acted synergistically to reduce the binding of activated T-cells, but CD44 antibodies alone had no effects. Activation of cyclic adenosine monophosphate (cAMP)dependent pathways inhibits TNF $\alpha$-induced ICAM-1 and VCAM-1 expression and T-cell adhesion [65].

Anti-CD3-stimulated peripheral blood T-cells also adhere to airway smooth muscle cells and upregulated ICAM-1 expression and induce the expression of major histocompatibility complex (MHC) Class II [66]. The induction of ICAM-1 was partly dependent on IFN $\gamma$. Bronchoalveolar lavage T-cells from atopic subjects following allergen challenge adhered to airway smooth muscle, with upregulation of ICAM-1 and human leukocyte antigen (HLA)DR. Stimulation of airway smooth muscle cells by IFN $\gamma$ leads to the expression of MHC Class II antigens, but airway smooth muscle cells were not capable of presenting alloantigen to CD4+ T-cells. CD40, a member of the TNF receptor family, is expressed on cultured human airway smooth muscle cells and is increased by TNF $\alpha$ or IFN $\gamma$ [40]. Cross-linking CD40 on airway smooth muscle cells resulted in enhanced IL-6 secretion and an increase in intracellular calcium concentrations. CD40-mediated signalling events include protein tyrosine phosphorylation and activation of the transcription factor, nuclear factor (NF)$\kappa \mathrm{B}[40]$.

\section{Effects of inflammatory factors on airway smooth muscle contractility}

Interactions of airway smooth muscle with inflammatory factors may lead directly to changes in airway smooth muscle contractility. Intratracheal administration of IL-1 $\beta$ to rats induced an attenuation of $\beta$-adrenergic receptorinduced airway relaxation through mechanisms involving a reduction in $\beta$-adrenoceptors and an increase in the inhibitory $\mathrm{G}$ protein, $\mathrm{G}_{\mathrm{i}} \alpha$ subunit, coupled to a reduction in adenylyl cyclase activity [67]. Similar observations were made with in vitro human airway smooth muscle cells incubated with IL-1 $\beta$ with a decreased response in muscle stiffness to isoprenaline mediated by uncoupling of $\beta$ receptors from stimulatory $\mathrm{G}_{\mathrm{s}}$-induced activation of adenylyl cyclase, perhaps through the release of $\mathrm{PGE}_{2}[68$, $69]$. TNF- $\alpha$ can also induce a reduction in isoprenalinestimulated adenylyl cyclase activity [70], together with increased expression of $\mathrm{G \alpha}_{1-2}$ and $\mathrm{G}_{\mathrm{q}} \alpha$ but not of $\mathrm{G}_{\mathrm{s}} \alpha$ proteins [71]. Passive sensitization of isolated rabbit airways with serum derived from atopic asthmatic subjects with high serum immunoglobulin ( $\mathrm{Ig}) \mathrm{E}$ levels demonstrated increased maximal isometric contraction and sensitivity to acetylcholine. There was also attenuation of relaxation of acetylcholine-induced contraction to isoprenaline $[72,73] . G_{i}$ protein expression was increased in sensitized airway smooth muscle, due to enhanced $\mathrm{G}_{\mathrm{i}} \alpha_{3}$ subunit, and increased muscarinic $\mathrm{M}_{2}$ receptor [71], ef-fects attributed to an induced release of IL-1 $\beta[74,75]$. Autocrine pro-inflammatory signalling and altered receptor/G protein-coupled second messenger accumulation and action may contribute to increase airway smooth muscle contractility in asthma and decrease responsiveness to $\beta$-adrenergic agonists. 
Atopic asthmatic serum-sensitized human tracheal smooth muscle cells exhibit mRNA and cell surface expression of the low affinity receptor for IgE, FceRII, an effect that was inhibited by pretreatment with anti-CD23 monoclonal antibody [75]. FCeRII is reported to be increased in asthmatic airway smooth muscle [76]. The anti-CD23 antibody blocked the increase in maximal isometric contractility to acetylcholine induced by serum-treated tracheal smooth muscle strips. Passive sensitization of human bronchial smooth muscle also increases both shortening velocity and capacity, and myogenic contractions to quick stretch, an effect that was related to IgE concentrations in sensitizing sera [77, 78]. Receptors for various cytokines have been found in airway smooth muscle cells passivelysensitized with atopic serum, such as receptors for IL-5, GM-CSF, IL-2, IL-12 and IFN $\gamma$. Thus, IL-5 and GM-CSF can increase acetylcholine contractility and reduce relaxant responses to isoprenaline [41], while IL-2 and IFN $\gamma$ prevented the increase in contractility to acetylcholine after passive sensitization. Airway smooth muscle from sensitized dogs demonstrates an increased velocity of shortening contributing to increased total shortening of the sensitized muscle but not isometric force, associated with increased gene and protein expression of myosin light chain kinase $[79,80]$.

Viral infections of the upper respiratory tract are recognized as important triggers of asthma exacerbations. Incubation of rhinovirus with airway smooth muscle cells increases airway smooth muscle responsiveness to acetylcholine and attenuated relaxation to isoprenaline, an effect related to diminished isoprenaline-induced cAMP accumulation and upregulated expression of $\mathrm{G}_{\mathrm{i}} \alpha_{3}$, effects that were triggered by binding of the rhinovirus to its ICAM-1 receptor in airway smooth muscle [81].

\section{Significance of in vitro observations on airway smooth muscle with regard to asthma}

Directly relating data obtained using cultured airway smooth muscle cells to in vivo circumstances is likely to be confounded by the tendency for phenotypic modulation of airway smooth muscle cells under normal cell culture conditions. In addition, it is still unclear exactly how a proliferative phase links with the synthetic phase which may be different for inflammatory cytokines or for contractile proteins such as smooth muscle $\alpha$-actin or heavy myosin chain. Nevertheless, the in vitro studies point to the potential of airway smooth muscle cells to both contribute to and to regulate the airway mucosal inflammatory process, as well as to be modified into a pro-inflammatory cell by the inflammatory milieu of the asthmatic airway (fig. 2). More evidence is required for these roles of the airway smooth muscle in vivo. There is some limited data. RANTES expression has been observed in airway smooth muscle cells in airway bronchial biopsies from healthy volunteers as well as from asthmatic subjects [26], while eotaxin immunoreactivity is reported in airway smooth muscle of airways from patients with asthma, with weaker staining in those from healthy volunteers [32], and of airways from guinea-pigs following allergen challenge [82]. Therefore, the production of chemokines in the airway smooth muscle may allow a gradient of chemotaxis to exist between the microvasculature and the airway smooth muscle, allowing T-cells, eosinophils, neutro-

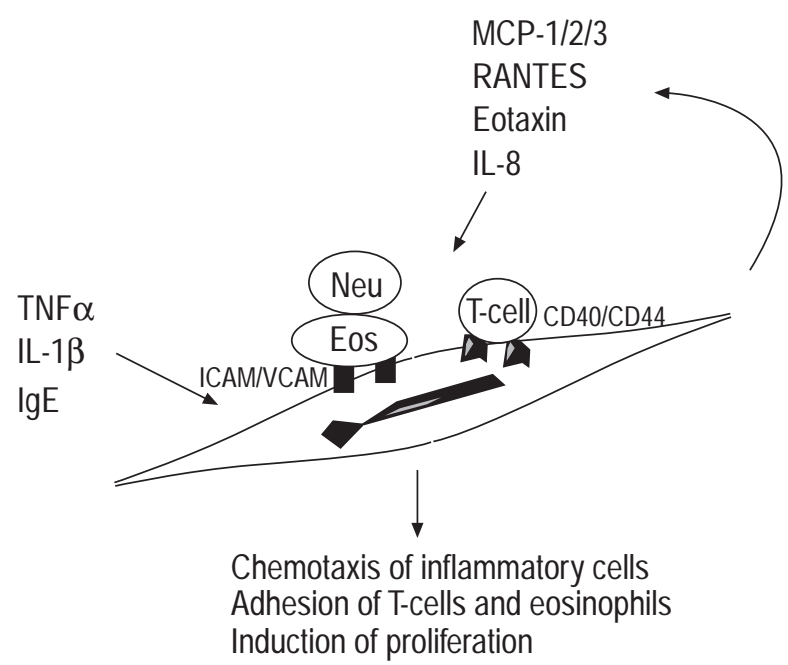

Fig. 2. - Some potential interactions between inflammatory cells, inflammatory mediators and airway smooth muscle cells. Pro-inflammatory stimuli such as tumour necrosis factor (TNF) $\alpha$, interleukin (IL) $-1 \beta$ or immunoglobulin (Ig)E may induce the release of chemokines/cytokines, and the expression of surface adhesion molecules or receptors. This leads to chemotaxis of inflammatory cells such as neutrophils (Neu), eosinophils (Eos), and T-cells, and to their adhesion to airway smooth muscle cells. This in turn may cause changes to airway smooth muscle such as induction of proliferation. Airway smooth muscle cells may promote and regulate airway inflammation, and airway smooth muscle mass. MCP: monocyte chemoattractant protein; RANTES: regulated upon activation, normal T-cell expressed and secreted; ICAM: intercellular adhesion molecule; VCAM: vascular cell adhesion molecule.

phils, and monocytes to accumulate around smooth muscle cells. Subsequent interactions with the smooth muscle may lead to proliferation or release of other cytokines. Their presence in airway smooth muscle cells from healthy subjects also begs the question of their role under normal physiological conditions.

In vitro studies also indicate that certain cytokines released by airway smooth muscle cells could interact in an autocrine fashion, and many examples can be deduced from the above description. For example, production of GM-CSF could induce the muscle to increase its own contractility.

Regarding the potential phenotypic changes, it is pertinent to ask whether airway smooth muscle cells during inflammation change phenotype to a more proliferative and synthetic type, rather than a contractile phenotype and whether some of the airway smooth muscle cells may change into a myofibroblast phenotype that is secretory. The migratory potential of myofibroblasts has been demonstrated following allergen challenge [83], but where they originate, within a matter of hours following allergen challenge, is unknown. Myofibroblasts have contractile properties and express actin filaments but not myosin, and the lineage relationship among fibroblasts, myofibroblasts and smooth muscle cells is not clear. Airway smooth muscle cells may be a source of myofibroblasts, possibly representing an airway smooth muscle cell in a synthetic phase. Proliferation of the smooth muscle cells may depend on its own elaboration of proliferative versus antiproliferative cytokines and mediators and whether the proliferative state is also associated with a secretory phase for certain cytokines/mediators remains to be determined. 


\section{Conclusion}

These new findings about the airway smooth muscle cell should change the perception of airway smooth muscle: far from being solely contractile, airway smooth muscle cells being influenced by inflammatory factors may participate in and regulate airway mucosal inflammatory processes by changing the phenotype and by secreting pro-inflammatory cytokines, mediators and enzymes. These could lead to interactions between the airway smooth muscle cells and inflammatory cells such as T-cells and eosinophils, as well as their surrounding matrix. New approaches to its study particularly in vivo are essential to determine whether these changes can occur in diseases such as asthma and chronic bronchitis. A complex relationship between airway smooth muscle contractility, its proliferative state, and its hypersecretory mode probably exists in disease and deserves further analysis.

This is of relevance to asthma therapy since the action of a $\beta_{2}$-adrenergic agonist may be less effective on airway smooth muscle that is in a hypersecretory or proliferative mode. The effects of a $\beta_{2}$-adrenoceptor agonist on hypercontractile airway smooth muscle may also be diminished, and could also be another reason for reduced effectiveness of $\beta_{2}$-adrenoceptor agonists such as occurs during exacerbations of asthma. Because airway smooth muscle cells can produce inflammatory cytokines, they could be considered as a target for anti-inflammatory therapy in asthma, such as corticosteroids. Corticosteroids can inhibit the induced release of RANTES, IL-8, GM-CSF and MCP-1 from airway smooth muscle cells in vitro, although they are not effective in inhibiting eotaxin release. In addition, they inhibit thrombin-induced airway smooth muscle proliferation through an inhibition of cyclin protein expression [84, $85]$.

Targeting the airway smooth muscle cell in terms of inhibition of its proliferative and secretory potential may represent a likely successful path for novel treatments that could prevent its excessive contractility and increased thickening in asthma.

\section{References}

1. Stephens NL, Li W, Wang Y, Ma X. The contractile apparatus of airway smooth muscle. Biophysics and biochemistry. Am J Respir Crit Care Med 1998; 158: S80S94.

2. Seow CY, Schellenberg RR, Pare PD. Structural and functional changes in the airway smooth muscle of asthmatic subjects. Am J Respir Crit Care Med 1998; 158: S179S186.

3. Barnes PJ, Chung KF, Page CP. Infiammatory mediators of asthma: an update. Pharmacol Rev 1998; 50: 515-596.

4. Dunnill MS. The pathology of asthma with special reference to changes in the bronchial mucosa. J Clin Path 1960; 13: 27-33.

5. Ebina M, Takahashi T, Chiba T, Motomiya M. Cellular hypertrophy and hyperplasia of airway smooth muscle underlying bronchial asthma. Am Rev Respir Dis 1993; 148: 720-726.

6. Lambert RK, Wiggs BR, Kuwano K, Hogg JC, Pare PD. Functional significance of increased airway smooth muscle in asthma and COPD. J Appl Physiol 1993; 74: 27712781.

7. Panettieri RAJ. Cellular and molecular mechanisms regu- lating airway smooth muscle proliferation and cell adhesion molecule expression. Am J Respir Crit Care Med 1998; 158: S133-S140.

8. James AL, Pare PD, Hogg JC. The mechanics of airway narrowing in asthma. Am Rev Respir Dis 1989; 139: 242246.

9. Wang CG, Du T, Xu LJ, Martin JG. Role of leukotriene $\mathrm{D}_{4}$ in allergen-induced increases in airway smooth muscle in the rat. Am Rev Respir Dis 1993; 148: 413-417.

10. Panettieri RA Jr, Murray RK, Eszterhas AJ, Bilgen G, Martin JG. Repeated allergen inhalations induce DNA synthesis in airway smooth muscle and epithelial cells in vivo. Am J Physiol 1998; 274: L417-L424.

11. Salmon M, Walsh DA, Koto H, Barnes PJ, Chung KF. Repeated allergen exposure induces airway smooth muscle and epithelial cell DNA synthesis and airway remodeling in sensitised Brown-Norway rats. Eur Respir $J$ 1999; 14: 633-641.

12. Lazaar AL, Albelda SM, Pilewski JM, Brennan B, Pure E, Panettieri RA. Tlymphocytes adhere to airway smooth muscle cells via integrins and CD44 and induce smooth muscle cell DNA synthesis. $J$ Exp Med 1994; 180: 807-816.

13. Ma X, Wang Y, Stephens NL. Serum deprivation induces a unique hypercontractile phenotype of cultured smooth muscle cells. Am J Physiol 1998; 274: C1206-C1214.

14. Halayko AJ, Camoretti-Mercado B, Forsythe SM, et al. Divergent differentiation paths in airway smooth muscle culture: induction of functionally contractile myocytes. Am J Physiol 1999; 276: L197-L206.

15. Hirst SJ. Airway smooth muscle cell culture: application to studies of airway wall remodelling and phenotype plasticity in asthma. Eur Respir J 1996; 9: 908-918.

16. Hall IP, Kotlikoff M. Use of cultured airway myocytes for study of airway smooth muscle. Am J Physiol 1995; 268: L1-L11.

17. Halayko AJ, Salari H, Ma X, Stephens NL. Markers of airway smooth muscle cell phenotype. Am J Physiol 1996; 270: L1040-L1051.

18. Thyberg J, Hultgardh-Nilsson A. Fibronectin and the basement membrane components laminin and collagen type IV influence the phenotypic properties of subcultured rat aortic smooth muscle cells differently. Cell Tissue Res 1994; 276: 263-271.

19. Yamamoto M, Yamamoto K, Noumura T. Type I collagen promotes modulation of cultured rabbit arterial smooth muscle cells from a contractile to a synthetic phenotype. Exp Cell Res 1993; 204: 121-129.

20. Sanders M. Molecular and cellular concepts in atherosclerosis. Pharmacol Ther 1994; 61: 109-153.

21. Frid MG, Aldashev AA, Dempsey EC, Stenmark KR. Smooth muscle cells isolated from discrete compartments of the mature vascular media exhibit unique phenotypes and distinct growth capabilities. Circ Res 1997; 81: 940952.

22. Belvisi MG, Saunders MA, Haddad el B, et al. Induction of cyclo-oxygenase-2 by cytokines in human cultured airway smooth muscle cells: novel inflammatory role of this cell type. Br J Pharmacol 1997; 120: 910-916.

23. Pang L, Knox AJ. $\mathrm{PGE}_{2}$ release by bradykinin in human airway smooth muscle cells: involvement of cyclooxygenase-2 induction. Am J Physiol 1997; 273: L1132L1140.

24. Vadas P, Stefanski E, Wloch M, Grouix B, Van Den Bosch H, Kennedy B. Secretory non-pancreatic phospholipase $\mathrm{A}_{2}$ and cyclooxygenase- 2 expression by tracheobronchial smooth muscle cells. Eur J Biochem 1996; 235: $557-563$. 
25. Hakonarson H, Gandhi S, Strusberg L, Carter S, Grunstein MM. Altered 5-lipoxygenase, epoxide hydrolase, $\mathrm{LTC}_{4}$ synthase, gamma-glutamyl transpeptidase, and leukotriene $\mathrm{B}_{4}$ and cys-LT1 receptor expression in atopic asthmatic sensitised airway smooth muscle. Am J Respir Crit Care Med 1999; 159: A401.

26. Berkman N, Krishnan VL, Gilbey T, et al. Expression of RANTES mRNA and protein in airways of patients with mild asthma. Am J Respir Crit Care Med 1996; 154: 1804-1811.

27. Garcia Zepeda EA, Rothenberg ME, Ownbey RT, Celestin J, Leder P, Luster AD. Human eotaxin is a specific chemoattractant for eosinophil cells and provides a new mechanism to explain tissue eosinophilia. Nat Med 1996; 2: 449-456.

28. Lamkhioued B, Renzi PM, Abi Younes S, et al. Increased expression of eotaxin in bronchoalveolar lavage and airways of asthmatics contributes to the chemotaxis of eosinophils to the site of inflammation. J Immunol 1997; 159: 4593-4601.

29. Ying S, Robinson DS, Meng Q, et al. Enhanced expression of eotaxin and CCR3 mRNA and protein in atopic asthma. Association with airway hyperresponsiveness and predominant co-localization of eotaxin mRNA to bronchial epithelial and endothelial cells. Eur J Immunol 1997; 27: 3507-3516.

30. John M, Hirst SJ, Jose PJ, et al. Human airway smooth muscle cells express and release RANTES in response to Th-1 cytokines: regulation by Th-2 cytokines and corticosteroids. J Immunol 1997; 158: 1841-1847.

31. Chung KF, Patel H, Fadlon EJ, et al. Induction of eotaxin expression and release from human airway smooth muscle cells by IL-1 $\beta$ and TNF $\alpha$ : effects of IL-10 and corticosteroids. Brit J Pharmacol 1999; 215: 1145-1150.

32. Ghaffar O, Hamid Q, Renzi PM, et al. Constitutive and cytokine-stimulated expression of eotaxin by human airway smooth muscle cells. Am J Respir Crit Care Med 1999; 159: 1933-1942.

33. Pype J, Dupont L, Menten J, et al. Expression and release of MCP-1, MCP-2 and MCP3 by human airway smooth muscle cells: modulation by corticosteroids and Th2 cytokines. Am J Respir Cell Mol Biol 1999; 21: 528-536.

34. Watson ML, Grix SP, Jordan NJ, et al. Interleukin 8 and monocyte chemoattractant protein 1 production by cultured human airway smooth muscle cells. Cytokine 1998; 10: 346-352.

35. John M, Au BT, Jose PJ, et al. Expression and release of interleukin- 8 by human airway smooth muscle cells: inhibition by Th-2 cytokines and corticosteroids. $A m J$ Respir Cell Mol Biol 1998; 18: 84-90.

36. Pang L, Knox AJ. Bradykinin stimulates IL-8 production in cultured human airway smooth muscle cells: role of cyclooxygenase products. J Immunol 1998; 161: 25092515.

37. Saunders MA, Mitchell JA, Seldon PM, et al. Release of granulocyte-macrophage colony stimulating factor by human cultured airway smooth muscle cells: suppression by dexamethasone. Br J Pharmacol 1997; 120: 545-546.

38. Hallsworth MP, Soh CPC, Twort CHC, Lee TH, Hirst SJ. Cultured human airway smooth muscle cells stimulated by interleukin-1 beta enhance eosinophil survival. $A m J$ Respir Cell Mol Biol 1998; 19: 910-919.

39. Elias JA, Wu Y, Zheng T, Panettieri R. Cytokine- and virus-stimulated airway smooth muscle cells produce IL11 and other IL-6-type cytokines. Am J Physiol 1997; 273: L648-L655.

40. Lazaar AL, Amrani Y, Hsu J, et al. CD40-mediated signal transduction in human airway smooth muscle. J Immunol 1998; 161: 3120-3127.

41. Hakonarson H, Maskeri N, Carter C, Grunstein MM. Regulation of TH1- and TH2-type cytokine expression and action in atopic asthmatic sensitized airway smooth muscle. J Clin Invest 1999; 103: 1077-1087.

42. Hirst SJ, Barnes PJ, Twort CHL. Quantifying proliferation of cultured human and rabbit airway smooth muscle cells in response to serum and platelet-derived growth factor. Am J Respir Cell Mol Biol 1992; 7: 574581.

43. Hirst SJ, Barnes PJ, Twort CH. PDGF isoform-induced proliferation and receptor expression in human cultured airway smooth muscle cells. Am J Physiol 1996; 270 : L415-L428.

44. Stewart AG, Grigoriadis G, Harris T. Mitogenic actions of endothelin-1 and epidermal growth factor in cultured airway smooth muscle. Clin Exp Pharmacol Physiol 1994; 21: $277-285$.

45. Noveral JP, Bhala A, Hintz RL, Grunstein MM, Cohen P. Insulin-like growth factor axis in airway smooth muscle cells. Am J Physiol 1994; 267: L761-L765.

46. De S, Zelazny ET, Sonhrada JF, Sonhrada M. Interleukin1 beta stimulates the proliferation of cultured airway smooth muscle cells via platelet-derived growth factor. Am J Respir Cell Mol Biol 1993; 9: 645-651.

47. Amrani Y, Panettieri RA Jr, Frossard N, Bronner C. Activation of the TNF alpha-p55 receptor induces myocyte proliferation and modulates agonist-evoked calcium transients in cultured human tracheal smooth muscle cells. Am J Respir Cell Mol Biol 1996; 15: 55-63.

48. De S, Zelazny ET, Sonhrada JF, Souhrada M. Role of phospholipase $\mathrm{C}$ and tyrosine kinase systems in growth response of human airway smooth muscle cells. $\mathrm{Am} \mathrm{J}$ Physiol 1996; 270: L795-L802.

49. Panettieri RA, Yadvish PA, Kelly AM, Rubinstein NA, Kotlikoff MI. Histamine stimulates proliferation of airway smooth muscle and induces c-fos expression. $A m J$ Physiol 1990; 259: L365-L371.

50. Whelchel A, Evans J, Posada J. Inhibition of ERK activation attenuates endothelin-stimulated airway smooth muscle cell proliferation. Am J Respir Cell Mol Biol 1997; 16: 589-596.

51. Panettieri RA Jr., Goldie RG, Rigby PJ, Eszterhas AJ, Hay DW. Endothelin-1-induced potentiation of human airway smooth muscle proliferation: an ETA receptormediated phenomenon. Br J Pharmacol 1996; 118: 191197.

52. Panettieri RA, Tan EM, Ciocca V, Luttmann MA, Leonard TB, Hay DW. Effects of $\mathrm{LTD}_{4}$ on human airway smooth muscle cell proliferation, matrix expression, and contraction in vitro: differential sensitivity to cysteinyl leukotriene receptor antagonists. Am J Respir Cell Mol Biol 1998; 19: 453-461.

53. Salmon M, Walsh D, Huang T-J, et al. Involvement of cysteinyl leukotrienes in airway smooth muscle DNA synythsis after repeated allergen exposure in sensitised Brown-Norway rats. Brit J Pharmacol 1999; 127: 11511158.

54. Salmon M, Liu YC, Rousell J, et al. Endothelin-1 expression in the lungs of sensitised Brown-Norway rats after repeated allergen exposure: contribution to increased airway smooth muscle and epithelial proliferation. $\mathrm{Am} \mathrm{J}$ Respir Crit Care Med 2000; (in press).

55. Patel H, Belvisi MG, Donnelly LE, Yacoub M, Chung $\mathrm{KF}$, Mitchell JA. Constitutive expression of type 1 NOS 
in human airway smooth muscle cells: evidence for antiproliferative role. FASEB J 1999; 13: 1810-1816.

56. Brar SS, Kennedy TP, Whorton AR, Murphy TM, Chitano P, Hoidal JR. Requirement for reactive oxygen species in serum-induced and platelet-derived growth factor-induced growth of airway smooth muscle. J Biol Chem 1999; 274: 20017-20026.

57. Rajah R, Nunn SE, Herrick DJ, Grunstein MM, Cohen P. Leukotriene $\mathrm{D}_{4}$ induces MMP-1, which functions as an IGFBP protease in human airway smooth muscle cells. Am J Physiol 1996; 271: L1014-L1022.

58. Rajah R, Nachajon RV, Collins MH, Hakonarson H, Grunstein MM, Cohen P. Elevated levels of the IGFbinding protein protease MMP-1 in asthmatic airway smooth muscle. Am J Respir Cell Mol Biol 1999; 20: 199-208.

59. Johnson PR, Armour CL, Carey D, Black JL. Heparin and PGE2 inhibit DNA synthesis in human airway smooth muscle cells in culture. Am J Physiol 1995; 269: L514L519.

60. Kassel O, Schmidlin F, Duvernelle C, Gasser B, Massard G, Frossard N. Human bronchial smooth muscle cells in culture produce stem cell factor. Eur Respir J 1999; 13: 951-954.

61. Johnson PR, Ammit AJ, Carlin SM, Armour CL, Caughey GH, Black JL. Mast cell tryptase potentiates histamineinduced contraction in human sensitized bronchus. Eur Respir J 1997; 10: 38-43.

62. Montefort S, Roche WR, Howarth PH, et al. Intercellular adhesion molecule 1 (ICAM-1) and endothelial leucocyte adhesion molecule-1 (ELAM-1) expression in the bronchial mucosa of normal and asthmatic subjects. Eur Respir J 1992; 5: 815-823.

63. Vignola AM, Campbell AM, Chanez P, et al. HLA-DR and ICAM-1 expression on bronchial epithelial cells in asthma and chronic bronchitis. Am Rev Respir Dis 1993; 148: 689-694.

64. Bentley AM, Durham SR, Robinson DS, et al. Expression of endothelial and leukocyte adhesion molecules interacellular adhesion molecule-1, E-selectin, and vascular cell adhesion molecule-1 in the bronchial mucosa in steady-state and allergen-induced asthma. J Allergy Clin Immunol 1993; 92: 857-868.

65. Panettieri RA Jr, Lazaar AL, Pure E, Albelda SM. Activation of cAMP-dependent pathways in human airway smooth muscle cells inhibits TNF-alpha-induced ICAM-1 and VCAM-1 expression and T lymphocyte adhesion. $J$ Immunol 1995; 154: 2358-2365.

66. Lazaar AL, Reitz HE, Panettieri RA Jr, Peters SP, Pure E. Antigen receptor-stimulated peripheral blood and bronchoalveolar lavage-derived T cells induce MHC class II and ICAM-1 expression on human airway smooth muscle. Am J Respir Cell Mol Biol 1997; 16: 38-45.

67. Koto H, Mak JC, Haddad EB, et al. Mechanisms of impaired beta-adrenoceptor-induced airway relaxation by interleukin-1beta in vivo in the rat. J Clin Invest 1996; 98 : 1780-1787.

68. Shore SA, Laporte J, Hall IP, Hardy E, Panettieri RAJ. Effect of IL-1 beta on responses of cultured human airway smooth muscle cells to bronchodilator agonists. $\mathrm{Am} \mathrm{J}$ Respir Cell Mol Biol 1997; 16: 702-712.

69. Laporte JD, Moore PE, Panettieri RA, Moeller W, Heyder J, Shore SA. Prostanoids mediate IL-1beta-induced betaadrenergic hyporesponsiveness in human airway smooth muscle ceils. Am J Physiol 1998; 275: L491-L501.
70. Emala CW, Kuhl J, Hungerford CL, Hirshman CA. TNFalpha inhibits isoproterenol-stimulated adenylyl cyclase activity in cultured airway smooth muscle cells. $\mathrm{Am} J$ Physiol 1997; 272: L644-L650.

71. Hotta K, Emala CW, Hirshman CA. TNF-alpha upregulates Gialpha and Gqalpha protein expression and function in human airway smooth muscle cells. Am J Physiol 1999; 276: L405-L411.

72. Hakonarson H, Herrick DJ, Grunstein MM. Mechanism of impaired beta-adrenoceptor responsiveness in atopic sensitized airway smooth muscle. Am J Physiol 1995; 269: L645-L652.

73. Hakonarson H, Herrick DJ, Serrano PG, Grunstein MM. Autocrine role of interleukin lbeta in altered responsiveness of atopic asthmatic sensitized airway smooth muscle. J Clin Invest 1997; 99: 117-124.

74. Hakonarson H, Herrick DJ, Serrano PG, Grunstein MM. Mechanism of cytokine-induced modulation of betaadrenoceptor responsiveness in airway smooth muscle. $J$ Clin Invest 1996; 97: 2593-2600.

75. Hakonarson H, Grunstein MM. Regulation of second messengers associated with airway smooth muscle contraction and relaxation. Am J Respir Crit Care Med 1998; 158: S115-S122.

76. Hakonarson H, Carter C, Kim C, Grunstein MM. Altered expression and action of the low-affinity IgE receptor FceRII (CD23) in asthmatic airway smooth muscle. $J$ Allergy Clin Immunol 1999; 104: 575-584.

77. Mitchell RW, Ruhlmann E, Magnussen H, Leff AR, Rabe KF. Passive sensitization of human bronchi augments smooth muscle shortening velocity and capacity. Am J Physiol 1994; 267: L218-L222.

78. Mitchell RW, Rabe KF, Magnussen H, Leff AR. Passive sensitization of human airways induces myogenic contractile responses in vitro. J Appl Physiol 1997; 83: 12761281.

79. Kong SK, Halayko AJ, Stephens NL. Increased myosin phosphorylation in sensitized canine tracheal smooth muscle. Am J Physiol 1990; 259: L53-L56.

80. Ma X, Stephens NL. The cytoskeleton and the extracellular matrix in sensitized canine tracheal smooth muscle. Respir Physiol 1997; 110: 57-66.

81. Hakonarson H, Maskeri N, Carter C, Hodinka RL, Campbell D, Grunstein MM. Mechanism of rhinovirusinduced changes in airway smooth muscle responsiveness. J Clin Invest 1998; 102: 1732-1741.

82. Humbles AA, Conroy DM, Marleau S, et al. Kinetics of eotaxin generation and its relationship to eosinophil accumulation in allergic airways disease: analysis in a guinea pig model in vivo. J Exp Med 1997; 186: 601-612.

83. Gizycki MJ, Adelroth E, Rogers AV, O'Byrne PM, Jeffery PK. Myofibroblast involvement in the allergen-induced late response in mild atopic asthma. Am J Respir Cell Mol Biol 1997; 16: 664-673.

84. Fernandes D, Guida E, Koutsoubos V, et al. Glucocorticoids inhibit proliferation, cyclin $\mathrm{D}_{1}$ expression, and retinoblastoma protein phosphorylation, but not activity of the extracellular-regulated kineses in human cultured airway smooth muscle. Am J Respir Cell Mol Biol 1999; 21: 77-88.

85. Stewart AG, Fernandes D, Tomlinson PR. The effect of glucocorticoids on proliferation of human cultured airway smooth muscle. Br J Pharmacol 1995; 116: 32193226. 